\title{
Faktor yang Menentukan Penggunaan Financial Technology Secara Berkelanjutan pada Pengguna Ovo di Jakarta Barat
}

\author{
Vicky Sandjaya Tanu Raja dan Sawidji Widoatmodjo \\ Program Studi Manajemen Fakultas Ekonomi dan Bisnis \\ Universitas Tarumanagara \\ Email: vickytanuraja@gmail.com
}

\begin{abstract}
The purpose of this study is to find out whether 1) economic benefit can affect fintech continuance intention; 2) convenience can affect fintech continuance intention; 3) trust can affect fintech continuance intention ; 4) attitude can affect fintech continuance intention. This study uses the OVO users at West Jakarta as many as 156 respondents and analyzed with SmartPLS 3.2.8. Those samples are collected with google form and use purposive sampling method. The results of this study indicate that economic benefit, convenience, trust, and attitude can affect fintech continuance intention and all of these variable have positive relationship toward fitech continuance intention.
\end{abstract}

Keywords: Economic Benefit, Convenience, trust, attitude, fintech contniuance intention.

Abstrak: Tujuan dari penelitian ini adalah untuk mengetahui apakah 1) economic benefit memiliki pengaruh yang signifikan terhadap fintech continuance intention; 2) convenience memiliki pengaruh yang signifikan terhadap fintech continuance intention; 3) trust memiliki pengaruh yang signifikan terhadap fintech continuance intetion; 4) attitude memiliki pengaruh yang signifikan terhadap fintech continuance intention. Penelitian ini menggunakan sampel yaitu pengguna OVO di Jakarta Barat sebanyak 156 responden dan dianalisa dengan SmartPLS 3.2.8. Sampel diperoleh melalui google form dan pemilihan sampel yang digunakan adalah teknik purposive sampling. Hasil penelitian ini menunjukkan bahwa economic benefit, convenience, trust, dan attitude memiliki pengaruh yang signifikan terhadap fintech continuance intention dan seluruh variabel tersebut memiliki hubungan yang positif terhadap fintech continuance intention.

Kata kunci: economic benefit, convenience, trust, attitude, fintech continuance intention, OVO, Jakarta Barat.

\section{LATAR BELAKANG}

Seiring perkembangan zaman yang semakin modern, teknologi informasi terus dikembangkan yang bertujuan untuk memudahkan hidup manusia. Pada saat ini, yang sangat ramai menjadi perbincangan dan baru saja berkembang di Indonesia adalah financial technology (Fintech). Industri fintech sangat berkembang pesat di Indonesia, hal tersebut ditandai dengan munculnya startup di bidang fintech yang menawarkan berbagai keunggulan dari produk yang mereka hasilkan. Menurut data yang diperoleh dari Otoritas Jasa Keuangan (OJK), terdapat 127 perusahaan fintech yang telah terdaftar secara resmi pada periode Juli 2019 dan tentunya setiap perusahaan fintech tersebut memiliki fitur-fitur yang menjadi layanan utama mereka kepada penggunanya.

Fintech yang kita ketahui menawarkan berbagai macam instrumen keuangan yang bertujuan untuk memudahkan masyarakat dalam mengakses produk-produk keuangan, 
mempermudah transaksi dan juga meningkatkan literasi keuangan seperti peer to peer $(\mathrm{P} 2 \mathrm{P})$ lending, crowd funding, dan payment gateway (alat pembayaran). Dari ketiga produk fintech tersebut, yang sangat ramai digunakan dikalangan anak muda sampai orang tua adalah payment gateway (alat pembayaran) yang menawarkan berbagai macam kemudahan kepada penggunanya untuk memudahkan mereka dalam melakukan pembayaran dan tentunya tidak jarang orang lebih senang menggunakan aplikasi payment gateway dibandingkan menggunakan uang tunai bahkan layanan perbankan yang telah mereka miliki.

Kemunculan fintech baru yang menyediakan layanan payment gateway tentunya akan menarik perhatian orang karena berbagai macam promosi yang salah satunya adalah pemberian cashback. Perusahaan penyedia layanan payment gateway berlomba-lomba menarik pengguna baru dengan memberikan cashback besar, misalnya dengan memberikan cashback sebesar 50\%. Ini membuat orang rela antri demi memperoleh produk yang lebih murah jika membayar menggunakan fintech daripada membayar dengan produk bank dan uang tunai. Selain promosi, kemudahan dalam melakukan transaksi yang ditawarkan oleh penyedia layanan payment gateway juga menjadi nilai jual untuk menarik pengguna baru, misalnya melakukan pembayaran tagihan (Listrik, telepon, dan lain-lain), dan dapat melakukan transfer uang sesama payment gateway dan antar bank cukup melalui aplikasi yang dibuat oleh perusahaan payment gateway tersebut, sehingga orang tidak perlu mengantri di mesin ATM atau loket pembayaran.

Tentunya hal tersebut telah menjadi faktor pendorong seseorang menggunakan fintech, yaitu memperoleh economic benefit dan convenience. Apakah karena promosi dan kenyamanan ini orang berminat menggunakan fintech? atau adakah hal lain yang menjadi daya tarik seseorang ingin dan mau menggunakan fintech?

Riset-riset yang telah dilakukan oleh para peneliti terdahulu yang membahas mengenai fintech di berbagai negara menemukan faktor-faktor yang bisa mempengaruhi minat orang dalam menggunakan fintech, diantaranya perceived benefit (economic benefit, seamless transaction, convenience), perceived risk (financial risk, legal risk, security risk, operational risk), trust, user statisfaction, confirmation, perceived usefulness, self-efficacy, attitude, dan masih banyak faktor lain yang dapat dijadikan sebagai gambaran dari minat seseorang dalam menggunakan fintech.

Namun dari sekian banyak faktor tersebut yang menonjol dari penelitian terdahulu antara lain economic benefit, convenience, trust, attitude, perceived usefulness, dan user statisfaction. Apakah faktor tersebut juga dapat dijadikan sebagai faktor yang mempengaruhi minat orang dalam menggunakan fintech di Indonesia? Untuk menjawab permasalahan ini, digunakan salah satu payment gateway adalah OVO sebagai objek studi ini. karena setiap tahunnya, terjadi kenaikan pada pengguna maupun transaksi OVO.

Berdasarkan informasi yang diperoleh dari Kontan.co.id, pada tahun 2018 pengguna OVO tumbuh sebesar $400 \%$ dengan volume transaksi sebesar 1 milyar transaksi, sementara pada tahun 2019 tumbuh sebesar 40\% dengan pertumbuhan jumlah nilai transaksi sebesar $55 \%$.

Di Indonesia memang terdapat beberapa perusahaan fintech yang menyediakan layanan payment gateway yang saling berlomba-lomba dalam menarik pengguna baru untuk mencoba dan merasakan kemudahan bertransaksi dari aplikasi payment gateway tersebut yang ramai digunakan oleh orang dalam bertransaksi diantaranya Gopay, OVO, dan Dana. 
Berdasarkan data dari Republika.co.id, Gopay berhasil mencatatkan transaksi 6,3 milyar dollar AS pada Februari 2019 sehingga OVO berada di urutan kedua setelah Gopay. Meskipun OVO belum mampu mengalahkan gopay dalam nilai transaksi, namun dilihat dari pertumbuhan jumlah transaksi yang dialami oleh OVO, muncul pertanyaan apa yang menjadi penyebab orang masih ingin menggunakan OVO secara berkelanjutan meskipun kalah dari pesaingnya yaitu Gopay?

Berdasarkan yang telah disampaikan di atas, menarik peneliti untuk melakukan penelitian terhadap pengguna OVO, untuk mengetahui secara spesifik dari penyebab orang menggunakan aplikasi OVO secara berkelanjutan sebagai alat pembayaran sehari-hari. Apakah dengan economic benefit yang diperoleh lebih dari yang ditawarkan oleh layanan perbankan sehingga orang beralih menggunakan fintech untuk bertransaksi. Apakah kenyamanan (convenience) transaksi yang ditawarkan oleh OVO kepada para penggunanya? Dengan kemudahan yang ditawarkan karena cukup melalui handphone saja tentunya membuat pengguna lebih senang karena cepat dan efisien dalam melakukan transaksi. Apabila pengguna telah melakukan transaksi menggunakan OVO apakah pengguna sudah percaya dan merasa aman kepada OVO terhadap uang yang mereka masukan ke aplikasi tersebut? Dan dari sekian banyak pengguna OVO yang telah melakukan transaksi menggunakan OVO apakah mereka menyukai atau tidak menyukai aplikasi tersebut sebagai metode pembayaran? sehingga penggunanya ingin menggunakan OVO secara berkelanjutan.

\section{KAJIAN TEORI}

Fintech merupakan hibridasi teknologi pada proses layanan keuangan tradisional dengan berbasis teknologi (Joyosumarno, 2018). Sehingga fintech diciptankan dengan tujuan untuk memudahkan setiap orang dalam melakukan transaksi melalui hand phone atau gadget. Dalam penggunaan fintech tersebut tentunya setiap perusahaan ingin penggunanya dapat menggunakan produk fintech tersebut secara berkelanjutan.

Penelitian ini menggunakan Theory Reason Action yang dikembangkan oleh (Ajzen \& Fishbein, 1980) telah digunakan secara luas sebagai model untuk memprediksi perilaku manusia dan kemudian dikembangkan oleh (Ajzen, 1991) menjadi Theory Planed Behaviour (TPB). Pada teori TRA, dijelaskan bahwa niat dari seseorang dapat terjadi oleh 2 faktor, yaitu attitude dan subjective norm yang kemudian dikembangkan menjadi TBP sehingga untuk memprediksi perilaku penggunaan tersebut dapat dilihat melalui oleh niat perilakunya dan pada gilirannya, niat tersebut secara bersama-sama ditentukan oleh Attitude, Subjective Norm dan perceived behavioral control. Variabel yang digunakan dalam penelitian ini yaitu economic benefit, convenience, trust, dan attitude sebagai faktor yang digunakan dalam menetukan penggunaan secara berkelanjuta.

Economic benefit didefinisikan sebagai pengurangan biaya dan keuntungan finansial yang diperoleh dari transaksi saat menggunakan fintech (Ryu, 2018). Menurut Lee (2009) benefit terdiri dari 2 kategori yaitu direct benefit dan indirect benefit dimana direct benefit merupakan keuntungan diperoleh pengguna secara langsung salah satunya penanganan biaya transaksi yang lebih murah, sedangkan indirect benefit merupakan keuntungan yang tidak dapat diukur dan tidak terlihat seperti transaksi dapat dilakukan dimana saja dan layanan tersedia 24 jam. Sehingga dapat disimpulka bahwa Economic benefit merupakan keuntungan dan berbagai kemudahan yang dapat dinikmati oleh pengguna dari sisi biaya yang 
dikeluarkan oleh pengguna dalam melakukan transaksi cinderung lebih murah daripada menggunakan layanan keuangan tradisional.

Convenience didefinisikan sebagai sebuah kombinasi antara waktu dan kegunaan (Kim, Mirusmonov dan lee, 2010). Menurut Okazaki dan Mendez (2013) convenience lebih mengarah kepada fleksibilitas waktu dan tempat untuk menggunakan fintech tersebut. Sehingga dapat disimpulkan bahwa merupakan kombinasi dari waktu dan tempat dimana penggunaan dari fintech mengarah pada fleksibilitas dan hal tersebut diharapkan dapat meningkatkan kenyamanan penggunanya dalam melakukan transaksi menggunakan fintech.

Trust didefinisikan sebagai dimesi dalam relasi bisnis yang menentukan tingkat dimana setiap pihak merasa dapat mengandalkan integritas dari janji yag ditawarkan oleh pihak lain (Kolsaker \& Payne, 2002). Trust merupakan salah satu faktor pendukung seseorang dalam menentukan pilihannya untuk menggunakan fintech secara berkala atau tidak, karena payment gateway yang digunakan untuk melakukan transaksi harus mengedepankan kepercayaan pelanggan atas uang yang mereka titipkan untuk digunakan dalam membayar keperluannya dan bertransaksi menggunakan aplikasi alat pembayaran tersebut.

Attitude didefinisikan sebagai suatu sikap yang didasari pada kecenderungan pisikologis yang terjadi dalam diri individu untuk menyukai ataupun tidak menyukai suatu objek yang digunakan oleh orang tersebut. Sehingga attitude dapat membuat seseorang ingin atau tidak menggunakan fintech secara berkelanjutan.

Continuance intention didefiisikan sebagai sejauh mana seseorang telah merumuskan rencana untuk terus melakukan beberapa perilaku tertentu di masa depan (Indrawati\&Putri, 2018).

\section{Kaitan Antar Variabel}

Economic benefit merupakan keuntungan dan berbagai kemudahan yang dapat dinikmati oleh pengguna dari sisi biaya sehingga terjadi kebiasaan yang dilakukan oleh pengguna untuk terus menggunakan fintech karena lebih murah daripada keuangan tradisional. Dilihat dari sisi fintech, economic benefit termasuk pengurangan biaya dan keuntungan dari transaksi keuangan melalui fintech (Ryu, 2018). Hal tersebut telah menjadi faktor pendorong seseorang menggunakan fintech secara berkelanjutan karena dengan menggunakan fintech untuk bertransaksi akan lebih murah dan menguntungkan dari sisi finansial daripada menggunakan layanan perbankan maupun uang tunai. Penelitian yang telah dilakukan oleh Ryu (2018), menunjukan bahwa economic benefit memiliki hubungan yang positif terhadap fintech continuance intention.

H1: Economic Benefit memiliki pengaruh yang signifikan terhadap fintech continuance intention.

Convenience atau kenyamanan merupakan kombinasi dari waktu dan tempat dimana penggunaan dari fintech mengarah pada fleksibilitas dan hal tersebut diharapkan dapat meningkatkan kenyamanan penggunanya dalam melakukan transaksi menggunakan fintech. Kenyamanan dan kemudahan fintech membuat penggunanya tidak perlu lagi membuang waktu untuk melakukan transaksi, cukup melalui handphone sudah dapat melakukan transaksi. Semakin nyaman orang menggunakan fintech untuk bertransaksi, orang tersebut akan terus menggunakan fintech untuk melakukan transaksi. Penelitian yang telah dilakukan oleh Kim, Mirusmonov dan lee, (2010), menunjukan bahwa convenience memiliki hubungan yang positif terhadap intention to use m-payment, temuan yang sama di dapat Gao \& 
Waechter (2015) perceived convenience memiliki pengaruh yang positif terhadap usage intention. Namun Mahapatra (2017) mendapati transaction convenience memiliki hubungan yang negatif terhadap intention to continue shopping on a mobile phone.

$\mathrm{H} 2$ : convenience memiliki pengaruh yang signifikan terhadap fintech continuance intention.

Trust merupakan salah satu faktor yang harus dipenuhi oleh penyedia payment gateway untuk menarik pengguna baru karena kepercayaan adalah tingkat dimana konsumen dapat mengandalkan integritas dan janji perusahaan fintech dalam menawarkan layanan keuangan (Kolsaker \& Payne, 2002). Jika pengguna telah memiliki kepercayaan terhadap perusahaan tersebut, maka pengguna tidak ragu atau cemas terhadap uang yang mereka simpan di aplikasi payment gateway tersebut untuk digunakan secara berkelanjutan.

Penelitian yang telah dilakukan oleh Koloseni \& Mandari, (2017), menunjukan bahwa trust memiliki hubungan positif terhadap continuance intention of mobile payment service. Temuan yang sama di dapat Indrawati \& Putri, (2018). Penelitian Azizah, et al, (2018), juga menunjukan bahwa trust memiliki hubungan yang positif terhadap continuance usage. Namun penelitian yang dilakukan oleh Susanto, et al, (2016) mendapati trust tidak memiliki pengaruh secara signifikan terhadap continuance use intention. Temuan yang sama juga diperoleh Cao, et al, (2018) menemukan trust memiliki hubungan yang negatif terhadap continuance intention. H3: Trust memiliki pengaruh yang signifikan terhadap fintech continuance intention.

Attitude merukapan suatu sikap yang didasari pada kecenderungan pisikologis yang terjadi dalam diri individu untuk menyukai ataupun tidak menyukai suatu objek yang digunakan oleh orang tersebut dan sikap ini yang menjadi penentu apakah orang tersebut ingin menggunakan fintech secara berkelanjutan atau tidak.

Penelitian Lee, (2009), menunjukan bahwa attitude memiliki hubungan yang positif terhadap intention to use mobile banking. Penelitian yang dilakukan oleh (Koloseni \& Mandari, 2017), menunjukan bahwa attitude memiliki hubungan yang positif terhadap continuance intention. Hal yang sama juga di temukan Praveena \& Thomas, (2014), bahwa attitude memiliki hubungan yang positif terhadap continuance intention. Sebaliknya José Liébana-Cabanillas, et al, (2014) mendapati attitude tidak memiliki pengaruh yang signifikan terhadap intention to use m-payment. H4: attitude memiliki pengaruh yang signifikan terhadap fintech continuance intention.

\section{METODOLOGI}

Desain penelitian ini bersifat eksplanatif dengan pendekatan kuantitatif, pengumpulan data dilakukan dengan kuisioner yang bersifat tertutup. Kuisioner dibagikan kepada pengguna OVO di Jakarta barat dengan pemilihan sampel menggunakan teknik purposive sampling. Untuk memperoleh sampel tersebut digunakan kriteria yang ditentukan oleh peneliti untuk dapat menjadi sampel penelitian yaitu memiliki dan menggunakan OVO dalam bertransaksi, telah menggunakan OVO minimal 6 bulan, berusia minimal 18 tahun, dan berdomisili di Jakarta Barat.

SmartPLS Penelitian ini akan menggunakan pendekatan PLS-SEM untuk mengolah data dengan software Smart PLS versi 3.2.8. Pengujian data dilakukan dengan tingkat keyakinan 
sebesar 95\%. Menurut Hair et all, (2011) Penilaian menggunakan PLS-SEM terdiri dari 2 langkah penilaian yaitu model pengukuran (outer model) dan model struktural (inner model), pengukuran outer model tidak dilakukan karena indikator yang digunakan telah diuji validitas serta reliabilitasnya oleh peneliti terdahulu sementara pengukuran inner model dilakukan dengan pengujian koefisien determinasi ( $\left.\mathrm{R}^{2}\right)$, Uji Effect Size $\mathrm{F}^{2}$, Goodness of Fit Model, serta uji hipotesis (Path Coefficient).

\section{HASIL UJI STATISTIK}

Data yang terkumpul sebanyak 196 responden, namun data yang akan digunakan dan sesuai dengan kriteria peneliti berjumlah 156 responden. Berdasarkan hasil uji koefisien determinasi, nilai R Square yang diperoleh sebesar 0,578 dan R Square Adjusted sebesar 0,567, sehingga $56 \%$ variabel continuance intention dapat dijelaskan oleh variabel economic benefit, convenience, trust, dan attitude sedangkan $44 \%$ dapat dijelaskan oleh variabel lain dengan hubungan antara variabel independen dengan variabel dependen masuk kedalam kategori moderate.

Berdasarkan hasil uji effect size, urutan variabel yang memiliki efek terbesar hingga terkecil adalah trust $(0,221)$, attitude $(0,122)$, economic benefit $(0,046)$, dan convenience $(0,026)$. Berdasarkan pengujian Goodness of Fit Model, penelitian ini memperoleh nilai sebesar 0,602 yang berarti tingkat kesesuaian dan kelayakan penelitian ini dapat dinyatakan besar. Berdasarkan hasil uji hipotesis dengan melihat $\mathrm{T}$ statistik $>1,65$ dan $\mathrm{p}$ value $<0,05$. Variabel yang digunakan pada penelitian ini yaitu economic benefit memperoleh nilai , convenience, trust, dan attitude seluruhnya berpengaruh secara signifikan terhadap fintech continuance intention dan berarah positif, sehingga hal ini mendukung H1, H2, H3, dan H4. Hasil pengujian bootsraping dapat dilihat pada gambar 1: 


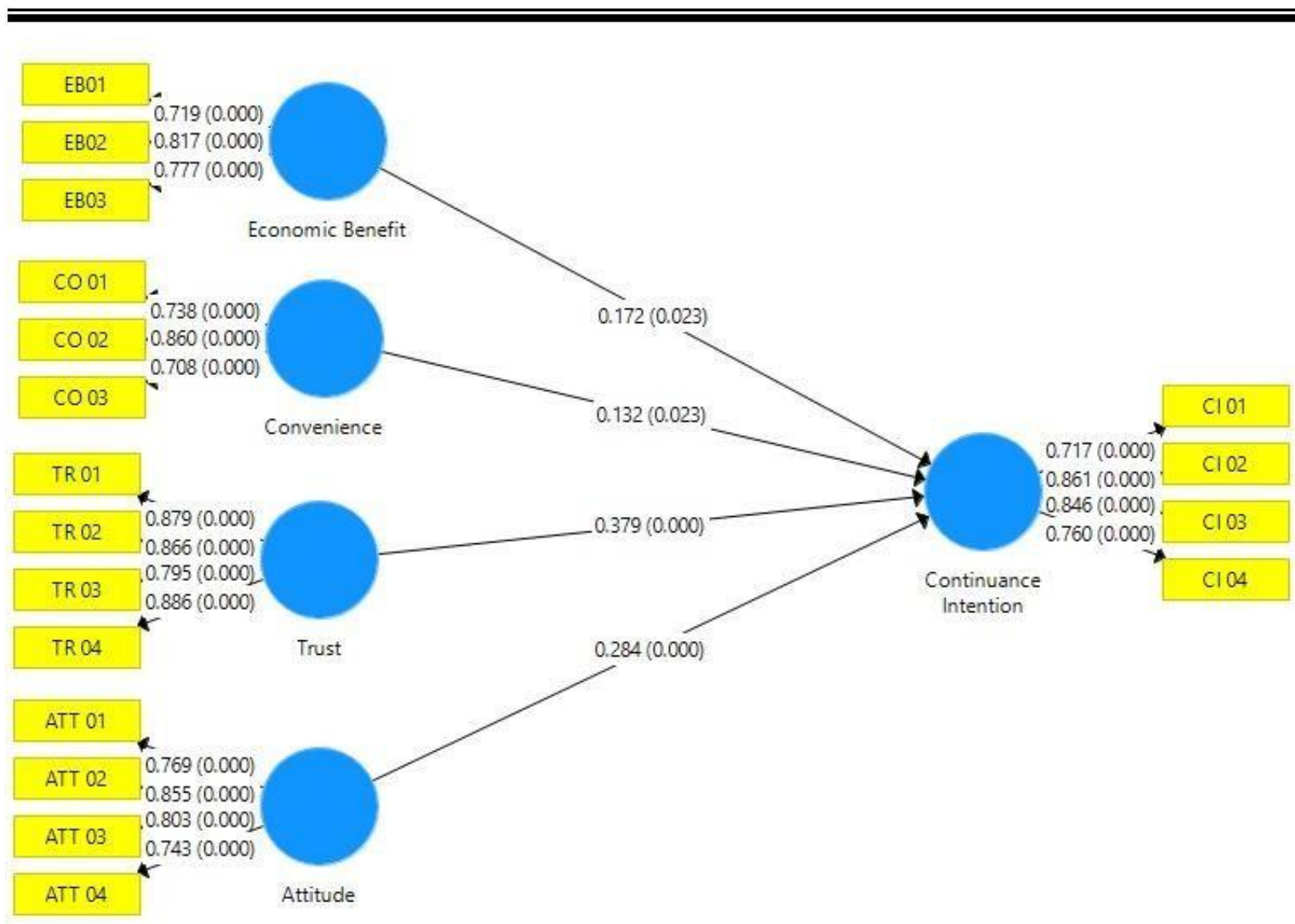

Gambar 1. Hasil uji bootsraping

\section{DISKUSI DAN KESIMPULAN}

Hasil yang diperoleh pada penelitian menunjukan economic benefit memiliki pengaruh yang signifikan terhadap fintech continuance intention dengan nilai $\mathrm{T}$ statistic $>1,65$ dan $\mathrm{p}$ value $<0,05$ sehingga $\mathrm{H} 1$ tidak ditolak. Economic benefit merupakan pengurangan biaya keuntungan finansial yang diperoleh saat menggunakan fintech (Ryu, 2018). Dengan adanya penghematan biaya yang diperoleh pengguna, maka pengguna tersebut akan merasa senang menggunakan fintech sebab biaya yang dikeluarkan tidak sebanyak pada saat menggunakan layanan keuangan tradisional. Faktor ini dapat dijadikan strategi bagi perusahaan untuk meningkatkan jumlah pengguna dengan memberikan berbagai promosi agar orang tertarik untuk menggunakan fintech. Berdasarkan pengujian hipotesis, hal ini sejalan dengan penelitian yang dilakukan oleh Ryu, (2018).

Convenience juga memiliki pengaruh yang signifikan terhadap fintech continuance intention dengan nilai $\mathrm{T}$ statistic $>1,65$ dan $\mathrm{p}$ value $<0,05$ sehingga $\mathrm{H} 2$ tidak ditolak. Convenience juga dapat dijadikan strategi bagi perusahaan untuk memperoleh pengguna baru dengan kemudahan dan efisiensi waktu yang ditawarkan oleh payment gateway tersebut, sehingga pengguna merasa nyaman saat menggunakan fintech dan hal ini menjadi nilai jual tersendiri selain dari economic benefit yang hanya memberikan efek yang tidak terlalu besar. Kenyamanan yang ditawarkan kepada penggunanya seperti kemudahan pembayaran tagihan sehari-hari, transfer antar bank hanya cukup melalui aplikasi tanpa antri di ATM, dan berbagai kemudahan lainnya dapat menjadikan seseorang ingin menggunakan fintech secara 
berkelanjutan. Berdasarkan pengujian hipotesis, hal ini sejalan dengan penelitian yang telah dilakukan oleh Kim, et al, (2010) dan Gao \& Waechter, (2015).

Trust memiliki pengaruh yang signifikan terhadap fintech continuance intention dengan nilai $\mathrm{T}$ statistik $>1,65$ dan $\mathrm{p}$ value $<0,05$ sehingga $\mathrm{H} 3$ tidak ditolak. Kepercayaan merupakan hal yang sangat sulit terutama pada bidang keuangan. Walaupun dalam hal ini pemerintah Indonesia membentuk badan pengawas berupa Otoritas Jasa Keuangan (OJK) namun tetap perlu dibangun kepercayaan dari pihak pengguna ke perusahaan serta pelayanan terhadap pengguna tersebut tidak mengecewakan. Apabila pengguna telah percaya terhadap perusahaan tersebut, maka pengguna tersebut tidak akan ragu untuk terus menggunakan fintech secara berkelanjutan karena merasa aman dengan uang yang mereka simpan pada produk tersebut. Berdasarkan dari hasil pengujian hipotesis, menunjukan penelitian ini sejalan dengan penelitian yang telah dilakukan oleh Koloseni \& Mandari, (2017) dan Azizah, et al, (2018).

Attitude memiliki pengaruh yang signifikan terhadap fintech continuance intention dengan nilai $\mathrm{T}$ statistik $>1,65$ dan $\mathrm{p}$ value $<0,05$ sehingga $\mathrm{H} 4$ tidak ditolak. Penduduk di Jakarta Barat masih kuat dengan pola penggunaan apabila mereka senang dengan produk yang mereka gunakan. Apabila orang lebih senang menggunakan layanan keuangan tradisional maka orang tersebut tidak akan beralih melainkan akan terus menggunakan layanan tersebut, meskipun pemerintah Indonesia telah melakukan kebijakan berupa transaksi nontunai. Sebaliknya apabila perusahaan berhasil mengubah pandangan orang bahwa penggunaan fintech untuk bertransaksi itu menyenangkan serta mudah untuk digunakan, maka orang akan menggunakan fintech secara berkelanjutan. Berdasarkan pengujian hipotesis, maka hasil yang diperoleh sejalan dengan penelitian yang dilakukan oleh Lee, (2009); Koloseni \& Mandari, (2017); Praveena \& Thomas, (2014).

Penelitian ini bertujuan untuk mengetahui faktor-faktor yang mempengaruhi penggunaan financial technology secara berkelanjutan dengan menguji variabel economic benefit, convenience, trust, dan attitude terhadap fintech continuance intention. Dari hasil yang diperoleh dapat disimpulkan bahwa keempat variabel tersebut memiliki pengaruh yang signifikan terhadap fintech continuance intention dengan seluruh hasil yang diperoleh berarah positif. Urutan variabel dengan efek terbesar sampai terkecil yaitu: trust, attitude, economic benefit, dan convenience.

\section{SARAN}

Berdasarkan hasil yang diperoleh dari penelitian ini, peneliti memberi saran kepada perusahaan dan berharap dapat bermanfaat serta diaplikasikan oleh perusahaan. Beberapa saran tersebut antara lain:

1. Economic benefit memiliki pengaruh yang signifikan terhadap fintech continuance intention sehingga perusahaan dapat memberikan promosi-promosi yang membuat penggunanya merasa hemat pada saat menggunakan OVO daripada menggunakan layanan keuangan tradisional, namun hal ini hanya memberikan pengaruh yang tidak terlalu besar terhadap penggunaan secara berkelanjutan.

2. Convenience memiliki pengaruh yang signifikan terhadap fintech continuance intention sehingga perusahaan perlu meningkatkan terus kenyamanan pengguna OVO melalui berbagai fitur pembayaran sehari-hari supaya penggunanya hanya 
cukup melakukan pembayaran melalui OVO daripada membayar manual maupun mengantri di ATM. Walaupun pengaruh yang diberikan lebih kecil daripada economic benefit namun apabila pelanggan diberi kemudahan dan kenyamanan selama menggunakan OVO, maka orang tidak akan ragu untuk menggunakan OVO secara berkelanjutan.

3. Trust memiliki pengaruh yang signifikan terhadap fintech continuance intention sehingga perusahaan harus menjaga serta meningkatkan kepercayaan pelanggan terhadap OVO karena pengaruh yang diberikan sangat besar. OVO harus mampu meningkatkan kinerjanya untuk meningkatkan kepercayaan pelanggan seperti meminimalisir kesalahan yang dapat muncul dari aplikasi OVO pada saat pengguna sedang bertransaksi dengan terus melakukan pengecekan rutin terhadap sistem serta keamanan dan peningkatan sistem bila diperlukan. Apabila kesalahan dapat dimimalisir dengan baik, diharapkan kepercayaan pengguna terhadap OVO dapat meningkat, selain itu OVO harus selalu siap apabila terjadi error dan pelanggan memerlukan bantuan OVO untuk menyelesaikan masalahnya.

4. Attitude memiliki pengaruh yang signifikan terhadap fintech continuance intention sehingga perusahaan harus mampu membuat pengguna baru maupun tetap merasa senang dalam menggunakan OVO karena pengaruh yang diberikan cukup besar, perusahaan dapat memberikan memberikan promosi setiap pembayaran menggunakan OVO, pelayanan atas keluhan pengguna ditanggapi secara maksimal dan memuaskan pengguna, nyaman menggunakan OVO karena dapat digunakan dimana saja dan kapan saja, dan uang yang disimpan di aplikasi serta data pengguna dijaga kerahasiaan dan keamanannya. Pengguna yang merasa senang akan terus menggunakan OVO daripada orang yang tidak senang saat menggunakan OVO.

\section{DAFTAR PUSTAKA}

Ajzen, I. (1991). The theory of planned behavior. Organizational Behavior and Human Decision Processes, 50(2), 179-211

Azizah, N., Putu, W, H., and Fatimah, A. (2018). Factors Influencing Continuance Usage of Mobile Wallets in Indonesia, 2018 International Conference on Information Management and Technology (ICIMTech), IEEE, 92-97.

Cao, X., Yu, L., Liu, Z., Gong, M., \& Adeel, L. (2018). Understanding mobile payment users' continuance intention: a trust transfer perspective. Internet Research, 28(2), 456-476.

Hair, J. F., Ringle, C. M., \& Sarstedt, M. (2011). PLS-SEM: Indeed a Silver Bullet. Journal of Marketing Theory and Practice, 19(2), 139-152.

Indrawati, dan Dianty A. P. (2018). Analyzing Factors Influencing Continuance Intention of EPayment Adoption Using Modified UTAUT 2 Model. 6th International Conference on Information and Communication Technology (ICoICT), 160-173.

José Liébana-Cabanillas, F., Sánchez-Fernández, J., \& Muñoz-Leiva, F. (2014). Role of gender on acceptance of mobile payment. Industrial Management \& Data Systems, 114(2), 220-240.

Joyosumarto, Subarjo. (2018). BANKIR Kepemimpinan Lembaga Perbankan Abad ke-21. Jakarta: Elex Media Komputindo.

Kim, C., Mirsobit, M., In, L. (2010). An empirical examination of factors influencing the intention to use mobile payment. Computers in Human Behavior 26, 310-322. 
Koloseni, D., Herman, M. (2017). Why mobile money users keep increasing? Investigating the continuance usage of mobile money service in Tanzania, Journal of International Technology and Information Management, 26(2), 117-143

Kolsaker, A., \& Payne, C. (2002). Engendering trust in e-commerce: a study of gender- based concerns. Marketing Intelligence \& Planning, 20(4), 206-214

Lee, Ming-Chi (2009). Factors influencing the adoption of internet banking: An integration of TAM and TPB with perceived risk and perceived benefit. Electronic Commerce Research and Applications, 8(2009), 130-141.

Madden, T. J., Ellen, P. S., \& Ajzen, I. (1992). A Comparison of the Theory of Planned Behavior and the Theory of Reasoned Action. Personality and Social Psychology Bulletin, 18(1), 3-9.

Okazaki, Shintaro, \& Felipe Mendez. (2013). Exploring convenience in mobile commerce: Moderating effects of gender, Computers in Human Behavior 29, 1234-1242

Praveena, K., and Sam Thomas. (2014). Continuance intention to use Facebook: A study of perceived enjoyment and TAM, Bonfring International Journal of Industrial Engineering and Management Science 4(1), 24-29.

Ryu, Hyu-Sun (2018) What Makes Users Willing or Hesistant To Use Fintech?: The Moderating Effect of User Type. Industrial management \& Data Systems, 118(3), 541-569.

Susanto, A., Younghunn, C., \& Youngwook, C. (2016). Determinants of continuance intention to use the smartphone banking services, Industrial Management \& Data Systems, 116(3), $508-525$. 